\title{
STATUS OF THE NOBLE CRAYFISH ASTACUS ASTACUS (L.) \\ IN GERMANY : MONITORING PROTOCOL AND THE USE OF RAPD MARKERS \\ TO ASSESS THE GENETIC STRUCTURE OF POPULATIONS.
}

\section{R. SCHULZ}

Zoological Institute, Technical University,

Fasanenstrasse 3, D-38092 Braunschweig, Germany.

E-mail:R.Schulz@tu-bs.de.

\begin{abstract}
On the basis of a literature review and new studies in Brandenburg, northeast Germany, the status and the genetic structure of the noble craytish Astacus astacus (L.) in Germany are described. The present situation is characterized by a patchy distribution comprising at least 719 stocks, documented after 1990 . Stocks are mainly confined to the uppermost stretches of small streams or to small lakes without connection to other surface waters. As is typical of Europe, geographical isolation, inbreeding and genetic drift may play an important role in the population structure of the noble crayfish in Germany.
\end{abstract}

By means of RAPD-PCR, stocks in Brandenburg (Br1, $\mathrm{Br} 2$ and $\mathrm{Br}$ ), Schleswig-Holstein (SH) and Bavaria (B1 and B2) were analysed for their genetic structure. RAPD markers show high ability to separate significantly all investigated stocks as single populations. Mean non-dimensional distances were 5.8, 5.6 and 4.2 for $\mathrm{SH}-\mathrm{B}$, $\mathrm{SH}-\mathrm{Br}$ and $\mathrm{B}-\mathrm{Br}$ between-region comparisons, respectively. Values for within-region comparisons were 3.1 and 1.3 for $\mathrm{B}-\mathrm{B}$ and $\mathrm{Br}-\mathrm{Br}$, respectively. However, even the three different lakes located in Brandenburg, which are only about $20 \mathrm{~km}$ apart from each other, contained significantly distinguishable populations.

So far it is not possible to judge whether the distinct populations result from isolation of stocks or indicate local adaptations to the specific environmental conditions. The answer to this question is important with respect to conservational management and the design of restocking programmes. A decision tree for the inventory and monitoring of noble crayfish stocks is suggested, since some areas in the northeast of Germany may still contain many unknown stocks, which are of considerable importance for conservation.

Key-words : Astacus astacus, conservation genetics, freshwater decapod, geographical isolation, stocks monitoring programme. 


\section{LE STATUT DE L'ÉCREVISSE NOBLE ASTACUS ASTACUS (L.) EN ALLEMAGNE : PROTOCOLE DE SURVEILLANCE ET UTILISATION DES MARQUEURS RAPD POUR ESTIMER LA STRUCTURE GÉNÉTIQUE DES POPULATIONS.}

\section{RÉSUMÉ}

A partir d'une revue bibliographique et de mes propres études en Brandenburg, nord-est de l'allemagne, le statut et la structure génétique de l'écrevisse Astacus astacus (L.) en Allemagne sont décrits. La situation actuelle, documentée depuis 1990, est caractérisée par une distribution inégale comprenant au moins 719 stocks. Les stocks sont essentiellement confinés aux bras les plus en amont des petites rivières ou à de petits lacs sans connection avec d'autres eaux de surface. Comme il est classiquement décrit en Europe, l'isolement géographique, la reproduction intragroupe et la déviation génétique peuvent jouer un role important dans la structure de la population de l'écrevisse noble en Allemagne.

Les stocks de Brandenburg ( $\mathrm{Br} 1, \mathrm{Br} 2$ et $\mathrm{Br} 3)$, Schleswig-Holstein $(\mathrm{SH})$ et Bavière ont été analysés pour leur structure génétique en utilisant la technique RAPD-PCR. Le marqueur RAPD montre une grande capacité à séparer de façon significative tous les stocks étudiés en populations uniques. Les distances moyennes non-dimensionnelles étaient respectivement $5,8,5,6$ et 4,2 pour les comparaisons interrégions $\mathrm{SH}-\mathrm{B}$, $\mathrm{SH}-\mathrm{Br}$ et $\mathrm{B}-\mathrm{Br}$. Les valeurs pour les comparaisons intrarégions étaient respectivement 3,1 et 1,3 pour $\mathrm{B}-\mathrm{B}$ et $\mathrm{Br}-\mathrm{Br}$. De plus, les trois lacs situés en Brandenburg et séparés seulement d'environ $20 \mathrm{~km}$ ont des populations significativement distinctes.

Jusqu'à présent, il n'est pas possible de juger si les populations distinctes résultent de l'isolement des stocks ou si elles indiquent une adaptation locale aux conditions spécifiques de l'environnement. La réponse à cette question est importante en termes de gestion pour la défense de l'environnement et pour l'élaboration de programmes de réintroduction. Un arbre de décision pour l'inventaire et le contrôle des stocks d'écrevisses est proposé, puisque dans certains endroits du nord de l'Allemagne, il peut y avoir encore des stocks non inventoriés qui sont d'importance considérable pour la gestion de l'environnement.

Mots-clés : Astacus astacus, conservation génétique, décapode d'eau douce, isolement géographique, programme de contrôle des stocks.

\section{INTRODUCTION}

In addition to the noble crayfish Astacus astacus (L.), two other species are native to Germany : the stone crayfish Austropotamobius torrentium (Schrank) and the white-clawed crayfish Austropotamobius pallipes (Lereboullet) (HAGER, 1996 ; TROSCHEL, 1997). At least four non-native species also live here, having been introduced from the catchment region of the Black Sea or from America. A. astacus is a protected species according to national (National Wildlife and Conservation Law and National Endangered Species Act) and European conservation guidelines (EU Habitats Directive). The noble crayfish is found in nearly all parts of Germany, but the number of stocks is very low and the populations are small compared with those before the introduction of the crayfish plague (BOHL, 1987a). In the southern part of the country, the stocks show a patchy geographical distribution and mostly are restricted to more or less isolated areas of the surface water system (BOHL, $1987 \mathrm{~b})$. In many regions the stocks have been driven out of the lowland habitats they prefer and have moved to higher ground : for instance, in Bavaria $90 \%$ of the natural stocks are now found at altitudes between 500 and $800 \mathrm{~m}$ (BOHL, 1987a). About half the habitats are isolated from adjacent water regions by various kinds of barriers, such as 
ponds, pipeworks, waterfalls, dams or reservoirs. Although not investigated in detail, the same situation can be assumed for the other parts of Germany (DEHUS, 1990 ; TROSCHEL and DEHUS, 1993 ; BLANKE, 1998).

In principle the noble crayfish can inhabit very diverse bodies of water : standing or flowing, highly structured and with abundant vegetation, from the lowland plains into the mountains (BLOHM et al., 1994). They can include brooks, rivers, small pools, ponds and lakes. Manmade structures such as water-filled gravel or clay pits are also suitable habitats. In flowing waters the noble crayfish is found together with fish species of the salmonid and upper cyprinid regions (BOHL, 1989). It is often said that clear, cool and clean bodies of water are the preferred habitat of the noble crayfish. This widespread opinion is presumably based on the relict populations now remaining, which are commonly restricted to the upper reaches of small waters (distance from source : $2-15 \mathrm{~km}$; width : a few meters ; depth : often less than $50 \mathrm{~cm}$ ) (BOHL, 1987a; BOHL, 1995). Formerly, however, noble crayfish lived in many rivers, in brooks with warm water in summer, and in canals, ponds and lakes with suitable structures and living conditions (BLANKE, 1998).

Furthermore, the noble crayfish can live in water with slight to severe contamination ; it occupies not only clear bodies of water but those with moderate natural turbidity or even extremely eutrophic waters (BLANKE, 1998). However, its presence in nutrient-rich water is practically ruled out by low oxygen content, contamination by toxic substances (e.g., nitrogen compounds) and the mud that accompanies eutrophication. Most of the flowing waters it inhabits belong to the biologically defined quality classes I-II and II (BOHL, 1989 ; HAASE et al., 1989). According to laboratory experiments, crayfish seem relatively tolerant of pesticides. However, - only: acute toxicity values ( $96 h$ LC50) are available for Procambarus clarkii (Girard) (EVERSOLE et al., 1996) and it is almost impossible to predict the sensitivity of populations in the field from these data. In practice, noble crayfish are often found in forest or meadow brooks, which are usually not immediately adjacent to cultivated fields (BOHL, 1987a).

Deterioration : of water-quality (WESTMAN, 1985), habitat destruction (BLANKE, 1998), competition from allochthonous crayfish species (LENKOWA, 1962 ; SÖDERBÄCK, 1995 ; WESTMAN, 1995) and predation by large stocks of predatory fishes, like eell and perch (DEHUS, 1997), have had a strong negative impact on populations of noble craytish in Germany. Moreover, the spread of crayfish plague (caused by:the fungus Aphanomyces astaci Schikora), for which many allochthonous crayfish species-serve as a vector, is the most serious threat to native crayfish stocks.

Population sizes and degree of geographical isolation make it extremely interesting to characterize the genetic: structure of crayfish species. The genetic structure of A. astacus populations has been studied so far only on the allozyme level (FEVOLDEN and HESSEN, 1989 ; FEVOLDEN et al.; 1994). There: are several indications that DNA-level analysis can be very useful specifically for the investigation of small populations (HADRYS et al., 1992; MACARANAS et al., 1995 ; FRITSCH and RIESEBERG; 1996). Analyses on the basis of DNA markers are available, for example, for $A$. pallipes (SOUTY-GROSSET et al., 199.7) and. for Cherax quadricarinatus (von Martens) (MACARANAS et al:; 1995). In the present study RAPD-PCR (random amplified polymorphic $*$ DNA-polymerase chain reaction) (WELSH and MCCLELLAND, 1990 ; WILLIAMS et .al.,. 1990) was used for the characterization of $A$. astacus stocks and comparison of stocks in. Brandenburg, Bavaria and Schleswig-Holstein.

It can be assumed that an intensification of inventory and monitoring programmes in the northeast : of : Germany - will' reveal. a considerable number of unknown stocks. In Brandenburg alone, which comprises about $8.2 \%$.of the area of Germany, there exists more than 1;600 small lakes with an area between 1 and 5 ha (MIETZ; 1996), most of them not investigated in detail. 
The objective of this study is to assess the current status of A. astacus in Germany, and to evaluate the extent to which RAPD-marker results concerning the genetic structure of crayfish stocks can be used for conservation and management. Furthermore, a decision tree for the estimation and monitoring of $A$. astacus is suggested to assist in the systematic description of the present stocking situation.

\section{MATERIAL AND METHODS}

\section{Status review}

The present status of the noble crayfish $A$. astacus was reviewed using different literature sources (e.g. : HAASE et al. (1989); DEHUS (1990); KNUTH and MIETZ (1993) ; TROSCHEL and DEHUS (1993) ; DEHUS (1997); BLANKE (1998)). Table I indicates which items of information were used for the different states of Germany. If possible, inventories after 1990 were used for the review. Different groups of $A$. astacus within the same stream catchment $\left(\sim 30 \mathrm{~km}^{2}\right)$ were counted as one stock.

\section{Genetic analysis}

Genomic DNA was extracted from leg muscle tissue of 13-15 male individuals from the Koppelsee (B1, $0.6 \mathrm{ha}$ ), the Krummer See (B2, $3.2 \mathrm{ha})$ and the Neuenfelder See (B3, $3.8 \mathrm{ha}$ ) in Northeast Brandenburg and from stocks obtained from the Wielenbach stream, Bavaria (B1, Dr. E. Bohl), from a crayfish hatchery in Augsburg, Bavaria (B2, Dr. M. Keller) and from a crayfish hatchery in Oeversee, Schleswig-Holstein (SH, H. Jeske). Animals from both hatcheries were mixtures of different wild stocks from the respective region.

Approximately $100 \mathrm{mg}$ muscle tissue was used for a phenolic DNA extraction, DNA concentration was checked in a Beckman spectrophotometer. A Perkin Elmer 9600 PCR machine was used. Three different 10-base oligonucleotide primers (OPA7, OPA9, OPB12 ; Operon Technologies, USA) gave positive and reproducible results. A negative control (without DNA template) was included in every amplification run. PCR amplification products were separated according to size on agarose gels, stained with ethidium bromide and visualized on a UV transilluminator. Lambda DNA Eco 47 I (Serva) was included as a size marker. Methodology of DNA extraction, PCR runs and gel electrophoresis is described in detail in SCHULZ and SYPKE (1999). Each banding position on the agarose gel was considered a locus where genotypes were scored as present (1) or absent (0). Hierarchical cluster dendrograms were obtained by UPGMA (Unweighted Pair Group Method with arithmetic Average) analysis of the 0-1 matrix using the statistical package SPSS ${ }^{\circledR}$. Statistical evidence for different populations was drawn from T-test with UPGMA distances from a distance matrix for all individuals (SNEATH and SOKAL, 1973). All possible within-stock distances were compared with all possible between-stock distances (BURKE et al., 1991) : $P<0.05$ identifies two stocks as two different populations.

\section{Inventory and monitoring}

The design of a decision tree and monitoring is based on the assumption that a certain autochthonous species of interest (e.g. noble crayfish) should be investigated. The tree gives different options according to the information already available and according to the amount of additional data required (qualitative and/or quantitative). For each of the four levels of investigation intensity, an estimation of effort in terms of time is given. These values can vary considerably, depending on season, weather and habitat conditions. 


\section{RESULTS}

\section{Status review}

The numbers of stocks in the different federal states of Germany are summarized in Table I. Some of the figures are uncertain, since no general surveys have been undertaken since 1990, in some cases not even before 1990. Different groups of noble crayfish within the same stream catchment were counted as one stock. In total, about 719 stocks are present in Germany. This value is of course only an estimation, since the occurrence of crayfish has been studied in detail only in some areas. Comparison of numbers of stock with the area of the respective federal state reveals that in some regions the density of stocks is relatively high (e.g. North Rhine-Westfalia, Bavaria, Sachsen), while in others (e.g. Rhineland-Palatinate, Brandenburg, Lower Saxony) it is relatively low. In some states, the number of stocks has changed considerably during the last decade. For example, in North Rhine-Westfalia, about 32 stocks were documented in 1986 (MURL, 1986), of which 16 were assumed to be of natural origin. Today, their number has increased considerably as a result of extensive restocking programmes (pers. commun. : G. Feldhaus). Although the number of known stocks in Bavaria seems to be very high, it can be assumed that there are even more stocks present, which are not described so far (pers. commun. : E. Bohl).

\section{Table I}

Data sources for the status survey of $A$. astacus in different states in Germany. Different groups of individuals within one stream catchment were counted as one stock. Area refers to the percentage of the total area of Germany $\left(357,000 \mathrm{~km}^{2}\right)$.

\section{Tableau I}

Sources des données pour l'étude du statut de $A$. astacus dans différents états d'Allemagne. Différents groupes d'individus à l'intérieur d'un bassin hydrographique ont été comptés comme un seul stock. Les surfaces représentent les pourcentages de la surface totale de l'Allemagne $\left(357000 \mathrm{~km}^{2}\right)$.

\begin{tabular}{lrrc}
\hline Federal state $^{1}$ & $\begin{array}{r}\text { No. of } \\
\text { stocks }\end{array}$ & $\begin{array}{c}\text { Area } \\
(\%)\end{array}$ & Reference \\
\hline Schleswig-Holstein & $14^{2}$ & 4.4 & DEHUS (1990) \\
Mecklenburg-Vorpommern & 19 & 6.5 & ZETTLER (1998) \\
North Rhine-Westfalia & $73^{3}$ & 9.5 & ANONYMUS (1998) ; pers. commun. : \\
& & & G. Feldhaus \\
Lower Saxony & 12 & 13.2 & BLANKE (1998) \\
Saxony-Anhalt & $18^{2}$ & 5.7 & MRLU (1997) \\
Brandenburg & 18 & 8.2 & KNUTH and MIETZ (1993) ; SCHUL and \\
& 182 & 5.9 & SYPKE (1999) \\
Hessen & $20^{2}$ & 4.6 & MEINEL (1999) \\
Thuringia & $30^{2}$ & 5.7 & MNLU (1996) \\
Saxony & 17 & 5.6 & SLL (1994) \\
Rhineland-Palatinate & $10^{4}$ & 0.7 & pommun. : T. Brenner and M. Ziesling \\
Saarland & 18 & 10.0 & Ders. Commun. : C. Klos \\
Baden-Württemberg & 288 & 19.8 & BOHL (1999) SCHADT (1995) \\
Bavaria & &
\end{tabular}

1 City states such as Berlin,. Hamburg and Bremen are excluded.

${ }^{2}$ Uncertain database, partly information from before 1990.

${ }^{3}$ See text (Results) for explanations.

${ }^{4}$ Survey programme started only in 1997. 
Figure 1 represents the geographical distribution of $A$. astacus in Germany. A single symbol in the map does not necessarily refer to only one occurrence. In some cases several groups close together in a small catchment area are represented by one symbol. Although the stocks are generally distributed over the whole country, the occurrence of noble crayfish in many areas is restricted to isolated ponds, headwater sections of small streams or tributaries. Large rivers of the lowlands such as the Ems, Weser, Elbe, Havel, Spree, Oder, Rhein, Main, Mosel, Danube, Regen, Lech or Isar mostly have lost their populations of noble crayfish.

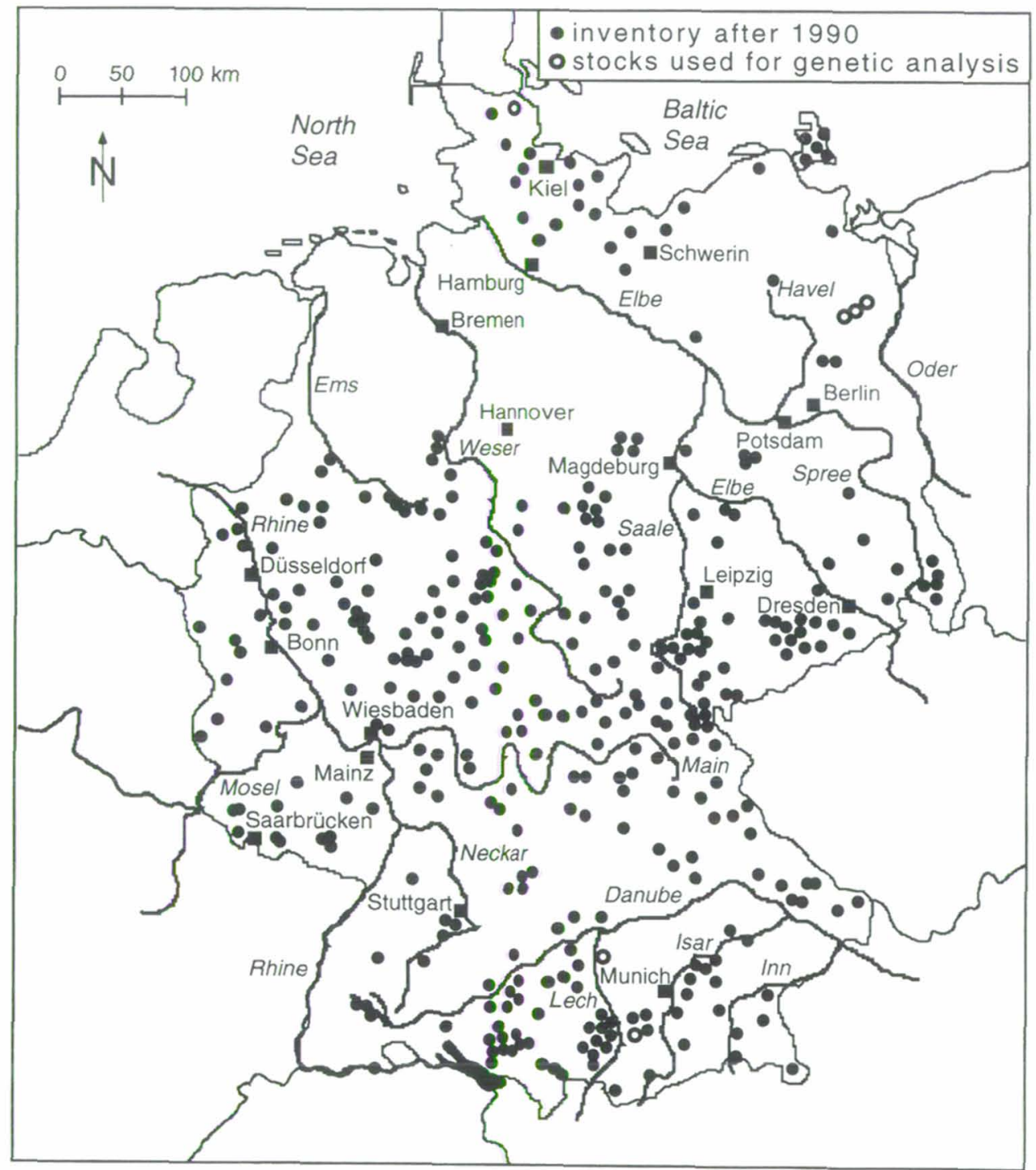

Figure 1

Map of the distribution of the noble crayfish A. astacus in Germany after 1990. The compilation of TROSCHEL and DEHUS (1993) served as a basis and has been supplemented by current information from various sources referring to specific states (see Table I).

\section{Figure 1}

Carte de distribution de l'écrevisse noble A. astacus en Allemagne après 1990. La compilation de TROSCHEL et DEHUS (1993) a servi de base et a été complétée par des informations actuelles de différentes origines qui font référence à des états spécifiques (voir Tableau I). 
For Schleswig-Holstein, DEHUS (1990) documented that about three quarters of the total stocks were living in stagnant waters. Similar findings have been reported for Thuringia (MNLU, 1996) and Brandenburg (KNUTH and MIETZ, 1993). According to BLANKE (1998), isolated fire ponds in forest areas serve as an important habitat for A. astacus in Lower Saxony. Ponds can sometimes contain considerable densities of noble crayfish. Own investigations of two small (0.6 and 3.2 ha) lakes in Brandenburg (SCHULZ and SYPKE, 1999) showed high population densities, with about 11,000 and 7,000 individuals per hectare lake area or about 2.2 and 3.2 adult individuals per meter shoreline. The proportions of juveniles were $90.9 \%$ and $85.6 \%$, respectively. According to HAASE et al. (1989) and ABRAHAMSSON (1966), these densities are representative of natural populations in suitable habitats. On the other hand, TREFZ and GROB (1996) documented a stock of about 6,000 to 20,000 individuals in a stretch of 3 to $4 \mathrm{~km}$ of a small brook (width : up to $3 \mathrm{~m}$; depth : up to $0.5 \mathrm{~m}$ ) in North Rhine-Westfalia.

\section{Genetic analysis}

A total of 51 bands was obtained from the three primers and were used in the subsequent analysis (Figure 2). All five populations could be significantly (UPGMA distance matrix, T-test, $\mathrm{P}<0.0001$ ) distinguished from one another (Table II). Unique bands for a population were observed, making possible the construction of a biochemical key for the unequivocal identification of the three populations of Bavaria and Schleswig-Holstein. Mean non-dimensional distances, calculated on the basis of individuals, were 5.8, 5.6 and 4.2 for the between-region comparisons $\mathrm{SH}-\mathrm{B}, \mathrm{SH}-\mathrm{Br}$ and $\mathrm{B}-\mathrm{Br}$, respectively. Values for within-region comparisons were 3.1 and 1.3 for $\mathrm{B}-\mathrm{B}$ and $\mathrm{Br}-\mathrm{Br}$, respectively (Table II). Therefore, distances among regions, as can be expected, were larger than distances between sites within the same region. Moreover, the differences between the two populations in Brandenburg were less than those between the two populations in Bavaria.

\section{Distance}

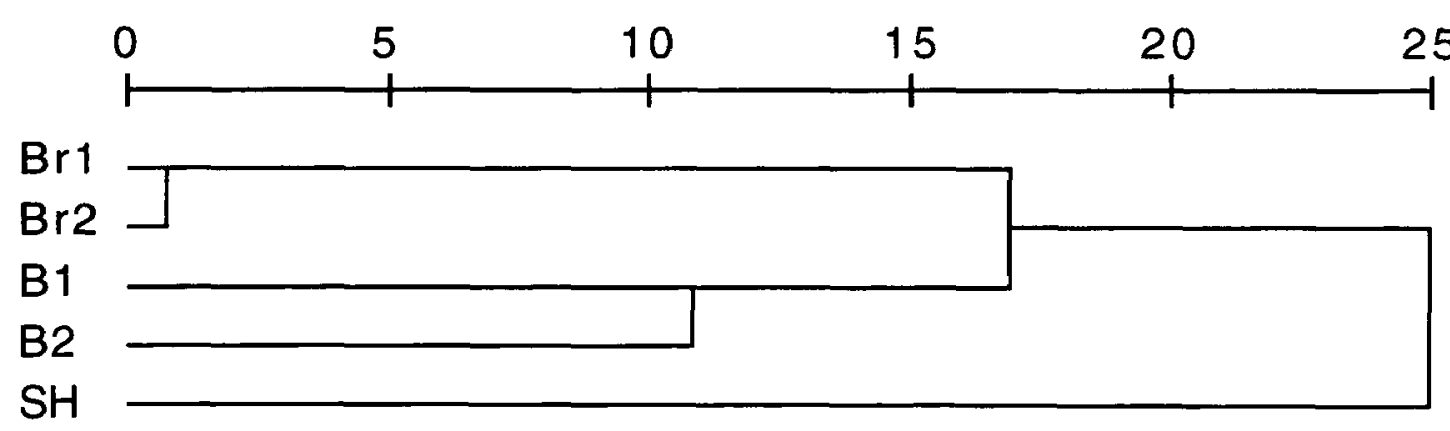

Figure 2

Dendrogram showing the similarities of five populations based on RAPD analysis (UPGMA analysis of median distances). Br1 and Br2 : Brandenburg, B1 and B2 : Bavaria, SH : Schleswig-Holstein.

\section{Figure 2}

Dendrogramme montrant les similarités de cinq populations, basé sur les analyses RAPD (analyses UPGMA des distanćes médianes). Br1 et $\mathrm{Br} 2$ : Brandenburg, B1 et B2 : Bavaria, SH : Schleswig-Holstein. 


\section{Table II}

Non-dimensional distances between two stocks in Brandenburg (Br1 and Br2), two stocks in Bavaria (B1 and B2), and one stock in Schleswig-Holstein (SH) based on UPGMA distance matrix. Significance levels refer to T-test for comparison of within-stock and between-stock differences $(p<0.05$ identifies two stocks as two different populations).

\section{Tableau II}

Distances non-dimensionnelles entre deux stocks en Brandenburg (Br1 et Br2), deux stocks en Bavière (B1 et B2) et un stock en Schleswig-Holstein (SH) basées sur UPGMA distance matrice. Les niveaux de signification font référence au T-test pour la comparaison des différences intra et interstocks ( $p<0,05$ identifient deux stocks comme deux populations différentes).

\begin{tabular}{lccccc}
\hline & $\mathrm{B} 1$ & $\mathrm{~B} 2$ & $\mathrm{SH}$ & $\mathrm{Br} 1$ & $\mathrm{Br} 2$ \\
\hline $\mathrm{B} 1$ & & $\mathrm{p}<0.0001$ & $\mathrm{p}<0.0001$ & $\mathrm{p}<0.0001$ & $\mathrm{p}<0.0001$ \\
$\mathrm{~B} 2$ & 3.1 & & $\mathrm{p}<0.0001$ & $\mathrm{p}<0.0001$ & $\mathrm{p}<0.0001$ \\
$\mathrm{SH}$ & 4.6 & 7.0 & & $\mathrm{p}<0.0001$ & $\mathrm{p}<0.0001$ \\
$\mathrm{Br} 1$ & 3.0 & 4.6 & 5.3 & & $\mathrm{p}<0.0001$ \\
$\mathrm{Br} 2$ & 4.1 & 4.9 & 5.9 & 1.3 & \\
\hline
\end{tabular}

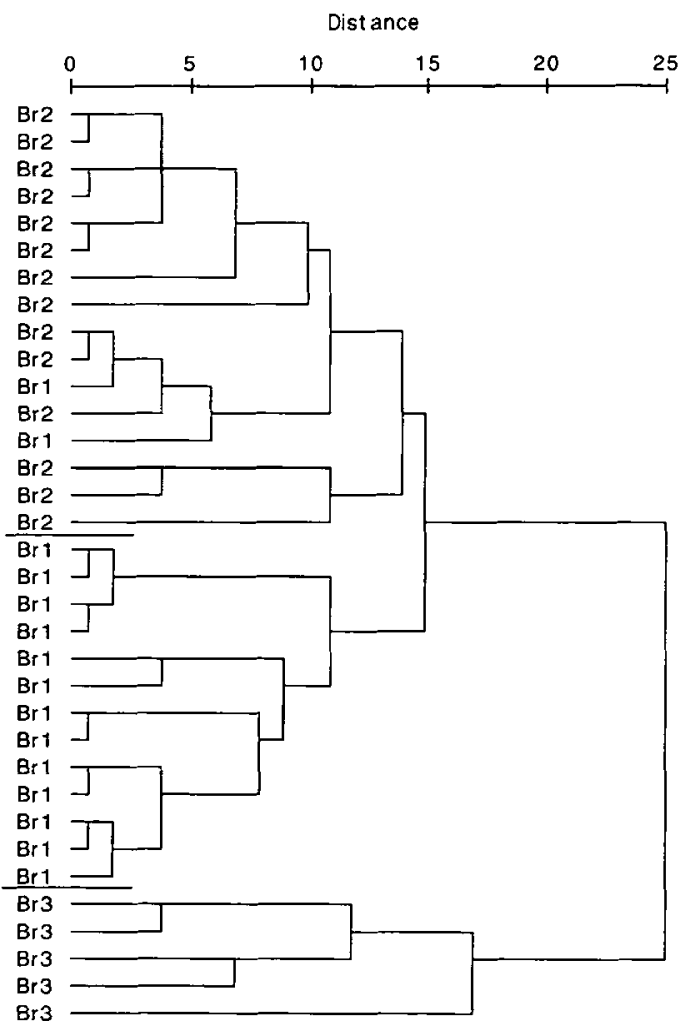

Figure 3

Dendrogram showing the similarities of three stocks in Brandenburg based on RAPD analysis (UPGMA analysis of distances on individual level) : Br1, Br2 and Br3. Numbers refer to individuals.

Figure 3

Dendogramme montrant les similarités de trois stocks en Brandenburg basé sur les analyses RAPD (analyses UPGMA des distances au niveau individuel) : Br1, $\mathrm{Br} 2$ et $\mathrm{Br}$. Les nombres font référence aux individus. 
In Figure 3, the two populations of Brandenburg were compared with a third stock (only five individuals due to very small population size) in another lake in the area. Geographical distances between the lakes are about $20 \mathrm{~km}$. Two individuals from the $\mathrm{Br} 1$ were grouped together with the $\mathrm{Br} 2$ individuals. However, even the three populations of Brandenburg can be differentiated significantly from each other (UPGMA distance matrix, T-test, $\mathrm{P}<0.0001$ ). Non-dimensional distances were 1.7 for $\mathrm{Br} 1-\mathrm{Br}, 4.9$ for $\mathrm{Br} 1-\mathrm{Br} 3$ and 4.2 for $\mathrm{Br} 2-\mathrm{Br} 3$.

\section{Inventory and monitoring}

On the basis of data from the literature and practical experiences, a decision tree for the inventory and monitoring of crayfish is proposed (Figure 4). The design of the decision tree is based on the assumption that a certain threatened autochthonous crayfish species (e.g. A. astacus) has to be monitored or that the stock status has to be demonstrated for a relatively large area without any previous information. The procedure is subdivided into four levels of investigation intensity, described in detail in Table III. The successive levels are associated with a progressively more sophisticated study design, which increases the effort in terms of time, but also makes more information available for an assessment of the stocking situation.

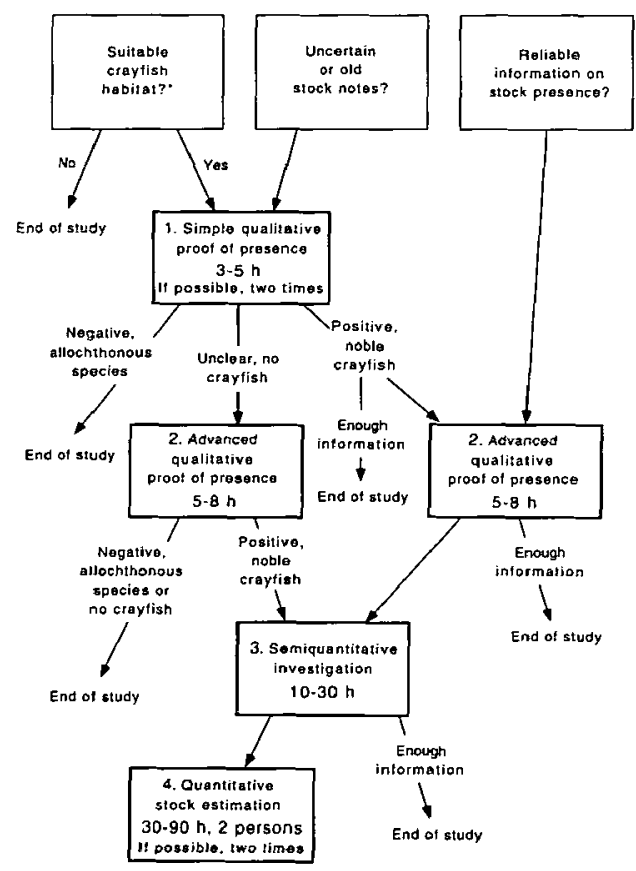

Figure 4

Decision tree for the monitoring of a particular autochthonous crayfish species (e.g. A. astacus). The tree gives different options according to the information already available and according to the amount of additional data required (qualitative and/or quantitative). For each of the four levels of investigation intensity, an estimate of effort in terms of time is given (see also Table III ; * see text for details).

\section{Figure 4}

Arbre de décision pour le contrôle d'espèces particulières d'écrevisses autochtones (par exemple A. astacus). L'arbre propose différentes options selon les informations déjà disponibles et selon la quantité d'informations supplémentaires nécessaires (qualitatives et/ou quantitatives). Pour chacun des quatre niveaux d'intensité de l'investigation, une évaluation de l'effort en termes de temps est fournie (voir aussi Tableau III ; * voir le texte pour plus de détails). 
Table III

Description of methods to be used in the four levels of investigation intensity during an $\boldsymbol{A}$. astacus estimation and monitoring programme (see also Figure 4).

\section{Tableau III}

Description des méthodes à utiliser dans une investigation à quatre niveaux d'intensité pour le programme d'estimation et de contrôle de $A$. astacus (voir aussi Figure 4).

\begin{tabular}{|c|c|c|c|}
\hline $\begin{array}{l}\text { Level of } \\
\text { investigation } \\
\text { intensity }\end{array}$ & $\begin{array}{c}\text { No. of sites and time } \\
\text { expenditure }\end{array}$ & $\begin{array}{l}\text { No. of } \\
\text { individuals to } \\
\text { be caught }\end{array}$ & $\begin{array}{l}\text { Parameters to } \\
\text { be monitored }\end{array}$ \\
\hline $\begin{array}{l}\text { 1. Simple qualitative } \\
\text { proof of presence }\end{array}$ & $\begin{array}{c}\text { Short survey at } 10 \text { sites or } \\
3 \text { traps for } 1 \text { night }\end{array}$ & $\begin{array}{l}\text { According } \\
\text { to catch }\end{array}$ & Adult/Juvenile $(\leq 8 \mathrm{~cm})$ \\
\hline $\begin{array}{l}\text { 2. Advanced } \\
\text { qualitative } \\
\text { proof of presence }\end{array}$ & $\begin{array}{l}\text { Longer survey of a } 100 \mathrm{~m} \\
\text { stretch or } 10 \text { traps for } \\
1 \text { night }\end{array}$ & $10-30^{x}$ & $\begin{array}{l}3 \text { size classes }{ }^{1}, \text { sex, } \\
\text { diseases, mutilations, } \\
\text { deformities }\end{array}$ \\
\hline $\begin{array}{l}\text { 3. Semiquantitative } \\
\text { investigation }\end{array}$ & $\begin{array}{c}2-3 \text { replicate surveys } \\
\text { along a } 150 \mathrm{~m} \text { stretch or } \\
15 \text { traps along } 150 \mathrm{~m} \text { for } \\
2-3 \text { nights }\end{array}$ & $30-100$ & $\begin{array}{c}\text { Size, sex } \\
\text { diseases, mutilations, } \\
\text { deformities }\end{array}$ \\
\hline $\begin{array}{l}\text { 4. Quantitative } \\
\text { stock estimation }\end{array}$ & $\begin{array}{c}\text { 3-5 replicate surveys } \\
\text { along a } 250 \mathrm{~m} \text { stretch or } \\
25-50 \text { traps along } 250 \mathrm{~m} \\
\text { for } 3-5 \text { nights }\end{array}$ & $>100$ & $\begin{array}{c}\text { Mark-recapture trapping, } \\
\text { juvenile sampling, } \\
\text { size, sex, diseases, } \\
\text { mutilations, deformities }\end{array}$ \\
\hline
\end{tabular}

Rough estimation : juvenile : $\leq 8 \mathrm{~cm}$; up to 5 years old : $\leq 12 \mathrm{~cm}$; older than 5 years : $>12 \mathrm{~m}$.

Level one is designed to get a preliminary idea about the presence or absence of the crayfish species under study. If possible, this investigation should be duplicated in different seasons to be sure about the result. Level two is appropriate to better characterize a known stock in a qualitative way, while at level three larger stream or shore stretches were included in a semiquantitative triplicated trapping design. If quantitative estimations of the population size are to be obtained, a quantitative mark-recapture study according to level four must be undertaken (Table III). For the estimation of juvenile densities, specific methods are necessary (BOHL, 1992 ; SCHULZ and SYPKE, 1999). Again, a duplication of the level four study in different seasons increases the reliability of the result. It should be pointed out that the investigation times given in Table III serve only as baseline information; they can differ considerably due to season, weather and habitat situation.

\section{DISCUSSION}

\section{Status review}

The original distribution of $A$. astacus is not clear. ALBRECHT (1983) assumes that the Main and the Rhine catchment areas had been the northern and western borders of its distribution. Stocks in the northern part were then only introduced by man. Until the middle of the last century, the noble crayfish was widely distributed throughout Germany (DRÖSCHER, 1906). Stocks were found in nearly all types of aquatic habitats, in sizes 
sufficient to allow extensive harvest and export (SMOLIAN, 1926). The introduction of crayfish plague, the invasion of infected crayfish and the extensive stocking of aquatic habitats with eel and other predatory fish can be identified as the main causes of the restrictions in distribution of the noble crayfish (BOHL, 1987b). The result is that a large proportion of the lowland brooks and rivers with suitable temperature conditions have been lost as habitats for $A$. astacus (BLANKE, 1998). According to BOHL (1987b), $38 \%$ of noble crayfish stocks in Bavaria were found in brooks separated from the downstream water system by various kinds of barriers. Although most of the lower stretches have reached a degree of water quality that should allow recolonization by crayfish, low migration rates (BOHL, 1987b) and non-aggressive competitive behaviour prevents rapid recolonization (SÖDERBÄCK, 1995). Isolated lakes and artificial ponds have become important as habitats for the noble crayfish (DEHUS, 1990 ; BOHL, 1995 ; BLANKE, 1998).

According to BLANKE (1998), about 155 stocks were present in Lower Saxony after 1920. It can be assumed that most of the losses of stocks due to crayfish plague occurred before this date (SMOLIAN, 1926). In view of this, the decrease to about 12 stocks documented after 1990 (BLANKE, 1998) is striking. Most of these stocks were confined to remote areas like the Harz Mountains. In the intensively cultivated areas (Braunschweiger Börde, Hildesheimer Börde and Osnabrücker hill country) numbers of stocks have decreased dramatically. It is likely that the intensification of agriculture, with increasing nutrient (HIGLER and REPKO, 1981), pesticide (SCHULZ, 1998) and sediment (SCHULZ, 1996) input, is responsible for this decline in populations.

However, dealing with numbers of stock for the different regions is difficult and can be misleading, since the intensity of investigation differs significantly between the federal states. However, the figures presented here can serve as a basis to assess future developments of the stocking situation in Germany.

\section{Genetic analysis}

The genetic structure of the noble crayfish has been monitored to facilitate intraspecific comparisons. The use of RAPD markers was undertaken on a preliminary basis to assess the potential of these markers for studies on $A$. astacus. Despite the consistent RAPD banding patterns obtained for each crayfish population, resolution of bands still requires some fine-tuning. RAPD profiles nevertheless promise to provide good discriminatory identification of wild $A$. astacus stocks.

The RAPD analysis indicates that the each stock studied belongs to a different population. Even sites as geographically close to one another as $20 \mathrm{~km}$ can contain genetically different populations. This information is of use for stock management and conservation of gene pools. The results also support the necessity of regulations for monitoring and restricting translocations of crayfish internationally and within Germany as outlined by BOHL (1987a) and MACARANAS et al. (1995). At present, it is not possible to judge whether low genetic variability among the individuals at one site is caused by adaptation to the specific local environment or by a loss of genotypes due to small population size, isolation, inbreeding and genetic drift. Further studies are necessary to answer this question, which is of considerable importance for restocking and management practice. However, the establishment of local hatcheries may help to reduce the risk of introducing crayfish of dubious origin and to produce stocking material which is well adapted to the particular environmental conditions.

On the basis of allozyme analysis, FEVOLDEN et al. (1994) reported low genetic variation for $A$. astacus. However, they found at least two loci indicating intra and interpopulation gene variation in noble crayfish. It seems that RAPD markers can be used effectively in identifying interpopulation gene variation, because of the high degrees of 
polymorphism achievable. RAPD markers will be extremely useful in checking the integrity of crayfish stocks as well as the identity of hybrids in mixed populations, something that morphology and allozyme typing probably are unlikely to do as efficiently (MACARANAS et al., 1995 ; FRITSCH and RIESEBERG, 1996).

\section{Inventory and monitoring}

Current research activities on noble crayfish in Germany mainly focus on diagnosis and prevention of various diseases and parasites, hatchery and restocking activities as well as environmental requirements of crayfish species. Specific statewide monitoring programmes, for which the state governments are responsible, have been undertaken only in very few cases. As pointed out, the status of crayfish species is generally unclear and often based on relatively old or unevaluated information. In practice, personnel for these investigations is not available or not equipped with the information necessary for an effective monitoring. A procedure and decision tree for the inventory and monitoring of crayfish stocks on a larger geographical scale is suggested. The general decision about suitability of a habitat for crayfish can be made according to informations from BOHL (1987a).

It can be assumed that in some areas with a high number of small isolated lakes (e.g. Mecklenburg-Vorpommern and Brandenburg), several unknown stocks exist and can be detected by the use of a simple monitoring programme. With respect to the genetic diversity and local adaptation which may be associated with these stocks, such monitoring programmes can be highly relevant for conservation.

\section{ACKNOWLEDGEMENTS}

I gratefully acknowledge the intensive cooperation of Julia Sypke, Braunschweig and Harald Wendt, Prenzlau, and the help of various persons with the field work. Dr. Erik Bohl, Dr. Max Keller and Helmut Jeske provided material from reference populations that was very helpful in carrying out the genetic analysis. Data about crayfish distribution were provided by the following persons (in alphabetical order) : Dr. T. Brenner, Ministerium für Umwelt und Forsten, Mainz ; Dr. P. Dehus, Fischereiforschungsstelle Langenargen ; G. Feldhaus, Landesanstalt für Fischerei, Albaum ; C. Klos, Fischereiverband Saar, Dillingen ; M. Pfeifer, Sächsische Landesanstalt für Landwirtschaft, Königswartha ; I. Podszuck, Deutsches Meeresmuseum, Stralsund ; Prof. Dr. G. Preuss, Uni Koblenz-Landau ; M. Ziesling, Landesamt für Umweltschutz und Gewerbeaufsicht, Oppenheim. Dr. Erik Bohl gave helpful comments on an earlier version of the decision tree for crayfish monitoring. Dr. Sabine Duquesne kindly translated parts of the manuscript into French.

\section{REFERENCES}

ABRAHAMSSON S., 1966. Dynamics of an isolated population of the crayfish Astacus astacus Linné. Oikos, 17, 96-107.

ALBRECHT H., 1983. Besiedlungsgeschichte und ursprüngliche holozäne Verbreitung der europäischen Flußkrebse. Spixiana, 6, 61-77.

ANONYMUS, 1998. 10000 Edelkrebse in Talsperren im Bergischen Land. LÖBF-Mitteilungen, 3/98, 4-5.

BLANKE D., 1998. Flußkrebse in Niedersachsen. Informationsdienst Naturschutz Niedersachsen, 18, 146-174. 
BLOHM H.P., GAUMERT D., KÄMMEREIT M., 1994. Leitfaden für die Wieder- und Neuansiedlung von Fischarten. Niedersächsisches Landesamt. für Ökologie, Hildesheim, 76-79 p.

BOHL E., 1987a. Comparative studies on crayfish brooks in Bavaria. Freshwater Crayfish, 7, 287-293.

BOHL E., 1987b. Crayfish stock and culture situation in Germany. Report from the Workshop on Crayfish Culture, 16-19 November, Trondheim, Norway, 87-90.

BOHL E., 1989. Untersuchungen an Flußkrebsbeständen. Bayerische Landesanstalt für Wasserforschung, Wielenbach, $237 \mathrm{p}$.

BOHL E., 1992. Bewertung von Krebsbeständen bei Gewässerschäden in natürlichen Gewässern ; methodische Ansätze, Grundlagen. Wertermittlungsforum, 10, 83-87.

BOHL E., 1995. Entwicklung von artbezogenen Gewässerleitbildern anhand von Kleinfischen und Krebsen. In Entwicklung von Zielvorstellungen des Gewässerschutzes aus der Sicht der aquatischen Ökologie, 391-404, Oldenbourg Verlag, München.

BOHL E., 1999. Crayfish stock situation in Bavaria - peculiar attributes, threats and chances. Freshwater Crayfish, 12, in press.

BURKE T., HANOTTE O., BRUFORD M.W., CAIRNS E., 1991. Multilocus and single locus minisatellite analysis in population biology studies. In BURKE T., DOLF T., JEFFREY J., WOLFF R. (eds.), DNA Fingerprinting. Approaches and applications, 154-168, Birkhäuser, Basel.

DEHUS P., 1990. Die Verbreitung der Flußkrebse (Decapoda, Astacidae, Cambaridae) in Schleswig-Holstein. Faunistisch-Ökologische Mitteilungen, 6, 95-105.

DEHUS P., 1997. Flußkrebse in Baden-Württemberg, Gefährdung und Schutz. Staatliche Lehr- und Versuchsanstalt, Aulendorf, Fischerei Forschungsstelle Baden-Württemberg, Langenargen, $24 \mathrm{p}$.

DRÖSCHER W., 1906. Der Krebs, seine Pflege und sein Fang. Verlag J. Neumann, Neudamm, $171 \mathrm{p}$.

EVERSOLE A.G., WHETSTONE J.M., SELLERS C., 1996. Handbook of relative acute toxicity values for crayfish. Sea grant consortium, Clemson, USA, $8 \mathrm{p}$.

FEVOLDEN S.E., HESSEN D.O., 1989. Morphological and genetic differences among recently founded populations of noble crayfish (Astacus astacus). Hereditas, 110, 149-158.

FEVOLDEN S.E., TAUGBOL T., SKURDAL J., 1994. Allozymic variation among populations of noble crayfish, Astacus astacus L., in southern Nonway. : implications for management. Aquaculture and Fisheries Management, 25, 927-935.

FRITSCH P., RIESEBERG L.H., 1996. The use of random amplified polymorphic DNA (RAPD) in conservation genetics. In SMITH T.B., WAYNE R.K. (eds.), Molecular genetic approaches in conservation, 54-73, Oxford University Press, New York.

HAASE T., HEIDECKE D., KLAPPERSTÜCK J., 1989. Zur Ökologie und Verbreitung des Edelkrebses Astacus astacus in der DDR. Hercynia, 26, 36-57.

HADRYS H., BALICK M., SCHIERWATER B., 1992. Application of random amplified polymorphic DNA (RAPD) in molecular ecology. Molecular Ecology, 1, 55-63.

HAGER J., 1996. Edelkrebse-Biologie, Zucht, Bewirtschaftung. Stocker, Graz-Stuttgart, $128 \mathrm{p.}$

HIGLER L.W.G., REPKO F.F., 1981. The effects of pollution in the drainage area of a Dutch lowland stream on fish and macroinvertebrates. Verh. Int. Ver. Limnol., 21, 1077-1082. 
KNUTH D., MIETZ O., 1993. Verbreitung, Gefährdung, Gewässeransprüche und Erhaltung des Edelkrebses Astacus astacus in Brandenburg. Naturschutz und Landschaftspflege in Brandenburg, 2/1993, 16-21.

LENKOWA A., 1962. Research on the crayfish Astacus astacus $L$. the causes of its disappearance, and the measures for its preservation and restitution in connection with the spreading of the American species Cambarus affinis Say. Ochrona Przyrody, 28, 1-38.

MACARANAS J.M., MATHER P.B., HOEBEN P., CAPRA M.F., 1995. Assessments of genetic variation in wild populations of the redclaw crayfish (Cherax quadricarinatus, von Martens 1868) by means of allozyme and RAPD-PCR markers. Marine Freshwater Research, 46, 1217-1228.

MEINEL W., 1999. Vorkommen der dekapoden Krebse in Hessen. Hessisches Ministerium für Landwirtschaft, Ernährung und Umwelt, Wiesbaden, $65 \mathrm{p}$.

MIETZ O., 1996. Die Verteilung der Seen im Land Brandenburg. Beiträge zur angewandten Gewässerökologie Norddeutschlands, 2, 166-168.

MNLU, 1996. Fische in Thüringen. Ministerium für Landwirtschaft, Naturschutz und Umwelt, Erfurt, 118 p.

MRLU, 1997. Die Fischfauna von Sachsen-Anhalt - Verbreitungsatlas. Ministerium für Raumordnung, Landwirtschaft und Umwelt, Magdeburg, $180 \mathrm{p}$.

MURL, 1986. Fische in Nordrhein-Westfalen. Ministerium für Umwelt, Raumordnung und Landwirtschaft, Düsseldorf, $126 \mathrm{p}$.

SCHADT J., 1995. Fische, Neunaugen, Krebse und Muscheln in Oberfranken. Bezirk Oberfranken-Fachberatung für Fischerei, Bayreuth, $145 \mathrm{p}$.

SCHULZ R., 1996. A field study on the importance of turbidity and bed load transport of sediments for aquatic macroinvertebrates and fishes. Verh. Ges. Ökol., 25, 247-252.

SCHULZ R., 1998. Macroinvertebrate dynamics in a stream receiving insecticidecontaminated runoff. Proc. Intern. Assoc. Theor. Appl. Limnol., 26, 1271-1276.

SCHULZ R., SYPKE J., 1999. Freshwater crayfish populations Astacus astacus (L.) in Northeast Brandenburg (Germany) : analysis of genetic structure using RAPD-PCR. Freshwater Craytish, 12, in press.

SLL, 1994. Die Fischfauna von Sachsen. Sächsiche Landesanstalt für Landwirtschaft, Dresden, $166 \mathrm{p}$.

SMOLIAN K., 1926. Der Flußkrebs, seine Verwandten und die Krebsgewässer. In DEMOLL R., MAIER H.N. (ed.), Handuch der Binnenfischerei Mitteleuropas, 423-524, Stuttgart.

SNEATH P.H., SOKAL R.R., 1973. Numerical Taxonomy. Freeman, San Francisco, 573 p.

SÖDERBÄCK B., 1995. Replacement of the native crayfish Astacus astacus by the introduced species Pacifastacus leniusculus in a Swedish lake : Possible causes and mechanisms. Freshwat. Biol., 33, 291-304.

SOUTY-GROSSET C., GRANDJEAN F., RAIMOND R., FRELON M., DEBENEST C., BRAMARD M., 1997. Conservation genetics of the white-clawed crayfish Austropotamobius pallipes: The usefulness of the mitochondrial DNA marker. Bulletin Fr. Pêche Piscic., 347, 677-692.

TREFZ B., GROß H., 1996. Populationsökologische Untersuchung zweier Edelkrebsvorkommen Astacus astacus (Linnaeus,1758) als Grunglage für den Artenschutz. Natur und Landschaft, 10, 423-429.

TROSCHEL H.J., 1997. In Deutschland vorkommende Flußkrebse : Biologie, Verbreitung und Bestimmungsmerkmale. Fischer und Teichwirt, 9, 370-376. 
TROSCHEL H.J., DEHUS P., 1993. Distribution of crayfish species in the Federal Republic of Germany, with special references to Austropotamobius pallipes. Freshwater Crayfish, 9, 390-398.

WELSH J., MCCLELLAND M., 1990. Fingerprinting genomes using PCR with arbitrary primers. Nucleic Acids Research, 18, 7213-7218.

WESTMAN K., 1985. Effects of habitat modification on freshwater crayfish. In ALABASTER J.S. (ed.), Habitat modifications and freshwater fisheries, 245-255, Butterworths, London.

WESTMAN K., 1995. Introduction of alien crayfish in the development of crayfish fisheries ; experience with signal crayfish (Pacifastacus leniusculus Dana) in Finland and the impact on the native noble craytish (Astacus astacus L.). Freshwater Craytish, 10, 1-17.

WILLIAMS J.G.K., KUBELIK A.R., LIVAK K.J., RAFALWESKI J.A., TINGEY S.V., 1990. DNA polymorphisms amplified by arbitrary primers are useful as genetic markers. Nucleic Acids Research, 18, 6531-6535.

ZETTLER M., 1998. Zur Verbreitung der Malascotraca (Crustacea) in den Binnen- und Küstengewässern von Mecklenburg-Vorpommern. Lauterbornia, 32, 49-65. 